Teosofia: Indonesian Journal of Islamic Mysticism, Volume 7, Number 2, 2018

\title{
ETHICS AND AESTHETIC VALUE OF SILK IN HADITHS
}

\author{
Azzah Nor Laila, Muhammad Idhom Dzulqarnain \\ Universitas Islam Nahdlatul Ulama Jepara \\ azzah@unisnu.ac.id
}

\begin{abstract}
Silk is one of the clothing products produced from the time of the Prophet to the present. But in terms of their use, rules and restrictions appear in the hadith of the Prophet. It seems that it has a message that the Prophet wants to convey to his people. This study aims to find the ethical and aesthetic values of silk in the perspective of the Prophet's hadith. Considering the development of fashion fashions made from silk experience development and sometimes its use is debated. The method used in this research is descriptive qualitative. The findings of this study indicate that the ethical values in the traditions surrounding silk can be grouped into three. First, ethics so that Muslims have a firm identity, not relying on other people. Second, ethics so that Muslims avoid arrogance and overdoing in decorating. Third, ethics cares about social affairs and lives simply. The aesthetic value of silk in the hadith can be seen from a variety of terms that refer to clothing made from silk, namely the recitation of harir, dibâj, qasiy, sundus, istabraq, siyara: The aesthetic value of the variety of clothing made from silk material during the Prophet's time is the uniqueness and variation of the pronunciation used by the Prophet to describe the shapes and structures of various silk types.
\end{abstract}

Keywords: ethics, aesthetics, silk, hadith.

\section{A. Introduction}

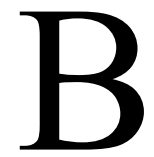
asically Islam encourages its people to look beautiful, clean, neat, organized and beautiful. Among them by enjoying and utilizing all the creations that God has bestowed upon him, in addition to taking care of himself also by utilizing natural products and the environment. It also becomes one of the roles of humans towards nature, which is utilizing its potential to meet the needs of human life and maintain its sustainability. The products of the earth, sea, plants, caterpillars and others can be processed with human effort and creativity to meet their daily needs. Both in the form of food, drinks, jewelry, and clothing. ${ }^{1}$ As the word of God in the Qur'an.

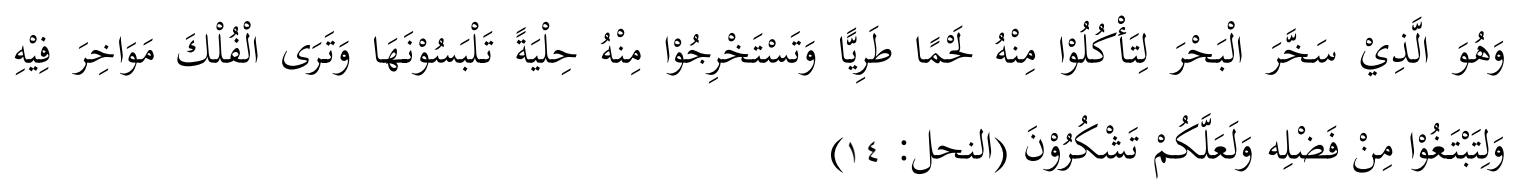

1 Muhammad Syamsuddin, "Eksistensi Manusia menurut K.H. Ahmad Azhar Basyir," Sosio Religia Jurnal Ilmu Agama dan Ilmu Sosial 4, November (2004), p. 138-139. 
"And it is He who subdues the sea (for you), so that you can eat fresh meat (fish) from it, and (from that sea) you take out the jewelry that you are wearing. You (also) see the boat sailing on it, and that you seek some of His gifts, and that you are grateful" (Q.S. an-Nahl: 14).

Clean life, decorate and look attractive are also included the advice of the Prophet. As the hadith of the Prophet.

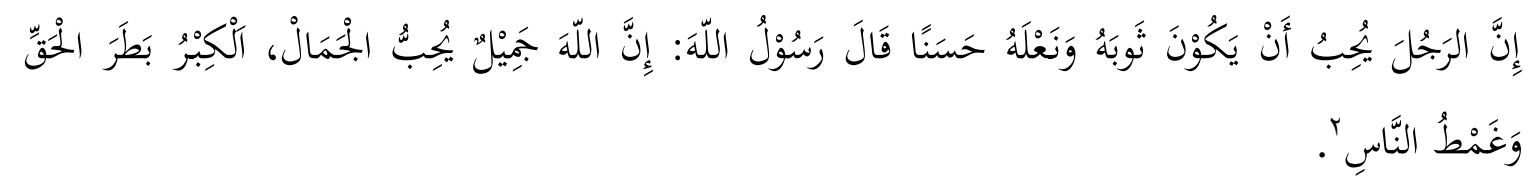

"Someone who likes beautiful clothes and beautiful footwear (is arrogance included?) "The Prophet replied," Verily, Allah is beautiful, pleased with beauty, pride is rejecting the truth and insulting others".

The Hadith contains the importance of paying attention to your beauty. The impact of beauty and personal hygiene is very influential on various aspects. The aspects of health, comfort and harmony of human social relations. Humans as social creatures cannot live individually. Humans need to interact, gather and socialize with others. So that the order of social life is also regulated in Islam, and becomes a means to achieve world happiness and the hereafter in a balanced manner. Likewise in the case of decorating yourself, although it is not forbidden but needs to be balanced with the afterlife.

So the Prophet gave rules and limits to humans in terms of clothing. One of them is in the hadith of the Prophet about the rules of using silk. There is a tradition that explains that the Prophet forbade the use of silk.

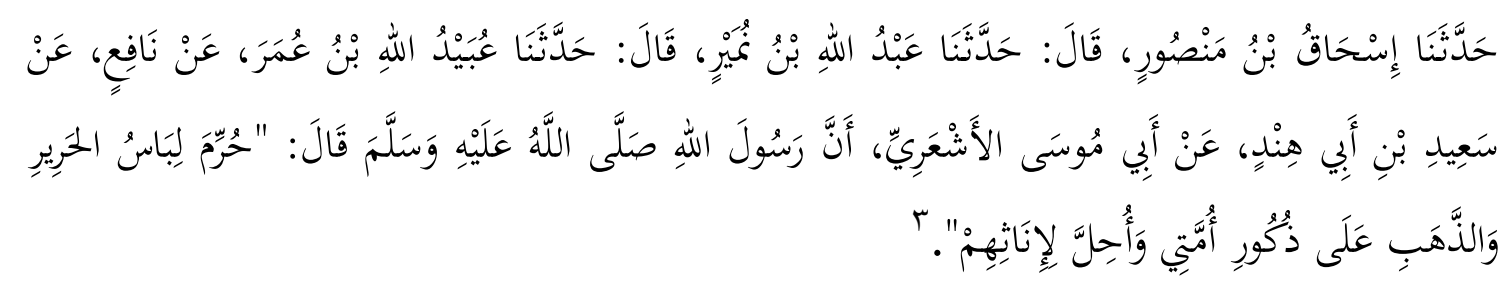

"Ishaq bin Mansur told us, he said: told us Abdullah bin Numair, he said: told us Ubaidullah bin Umar from Nafi ', from Sa'id bin Abi Hindin, from Abi Musa al'Asy'ary, Verily the Prophet said: "Forbidden silk clothing and gold for my people male and halal for women".

Whereas in other hadith texts, the limits with the prohibition of silk are addressed in general, not clearly specified for men or women.

\footnotetext{
2 Abu Abdullah Muhammad Bukhari, Al-Jami' al-Shahih (Kairo: al-Mathba'ah as-Salafiyyah, 1400), p. 432.

3 At-Tirmidzi Muhammad, Sunan al-Tirmidzi (Riyadl: Maktabah al-Ma'arif, 1417), p. 401.
} 


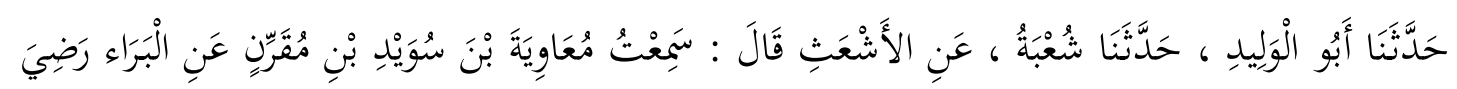

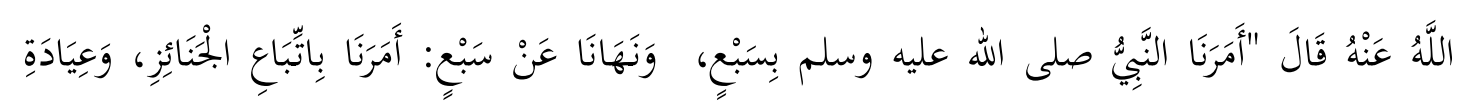

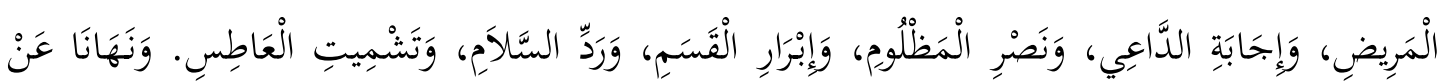

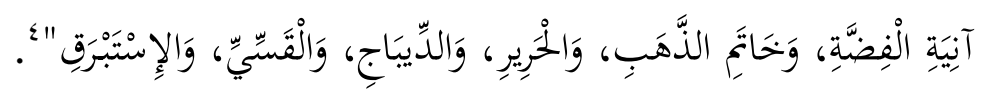

"Has told us Abu al Walid, told us the Syu'bah from al Ash'ats said: I have heard from Mu'awiyah bin Suwaid bin Muqarrin, from al Barra 'R.A. said: The Prophet has ordered us seven things and prohibited us from seven things. Ordered us to accompany the body, see the sick, answer calls, help the wrongdoers, fulfill oaths, answer greetings, and give thirsty people a drink. And forbid us from using silver containers or containers, wearing gold rings, silk, dibaj, qasiyyi, and istabraq".

In general the traditions that limit the use of jewelry or specific silk fabrics indicate there is an ethical message taught by the Prophet to his people. In another narration there is a tradition which explains that the Prophet used silk, which shows that the Prophet also paid attention to the aesthetic aspects of life. So in the case of using clothes or decoration also need to consider ethical and aesthetic values.

Silk is one of the clothing products produced from the time of the Prophet to the present. Currently, silk production has appeared with various variants, from the original label to imitation. Then what about silk products in the time of the Prophet. Therefore the study of hadith on silk becomes interesting, so that ethical and aesthetic values can be found from the use of silk based on the hadith of the Prophet.

In this study the authors used a qualitative approach. In collecting data the writer uses the thematic method, where the writer will study the hadith based on the theme with the approach of various scientific disciplines. ${ }^{5}$ In the process of collecting hadith data about the theme, the writer uses the method of takhrij bil mauḍ̂ 'and takhrij bil lafẓi. Through the keyword theme, the pronunciations in the eyes of the hadith both from the beginning, middle, or end. ${ }^{6}$ In data analysis, the authors use the content analysis method, to analyze the meaning and content of the hadith texts descriptively, critically and reflectively. Furthermore it is reflected in the present context.

\section{B. Ethics and Aesthetics}

Ethics is a norm that regulates human behavior. The simplicity of the ethics is essentially about good and bad or appropriate and whether or not human behavior matches the values that apply in a social order. In addition, the size of values (values) and norms are also related to aesthetic values. ${ }^{7}$

4 Bukhari, Al-Jami' al-Shahih, p. 383.

5 Syuhudi Ismail, Metodologi Penelitian Hadis Nabi (Jakarta: Bulan Bintang, 1992), p. 45-46.

6 Abdul Majid Khon, Ulumul Hadis (Jakarta: Amzah, 2010), p. 119-122.

7 Vera Sardila, "Implementasi Pengembangan Nilai-Nilai Etika dan Estetika Dalam Pembentukan Pola Prilaku Anak Usia Dini” 26, no. 2, (Juni, 2015), p. 89. 
Aesthetics theoretically according to Feldman include four aspects, namely aspects of function, form, structure and interaction, as well as meaning. ${ }^{8}$ While aesthetics in Islam does not mean that beauty is revealed as a destructive pleasure. But the form of beauty that brings goodness. So that aesthetics is a form of the creativity of a work that contains a unity of aesthetic and ethical values. ${ }^{9}$

\section{Silk}

Etymologically silk is a delicate material woven from fine and soft threads from a silkworm cocoon. ${ }^{10}$ The material is then used by humans as clothing, scarves or decoration. In Arabic silk is often referred to the word harir. In harir language means the type of clothing that is smooth and contains silk. ${ }^{11}$

The recitation of arir is also found in the Koran, including in the letter Fathir verse 33.

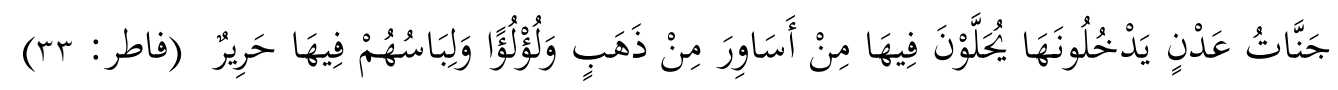

"(They will get) heaven" Adn, they entered into it, in which they were given bracelets of gold and pearls, and their clothes in them were silk".

Silk in the verse is described as the clothes of the inhabitants of heaven, as in surah alHajj verse 23.

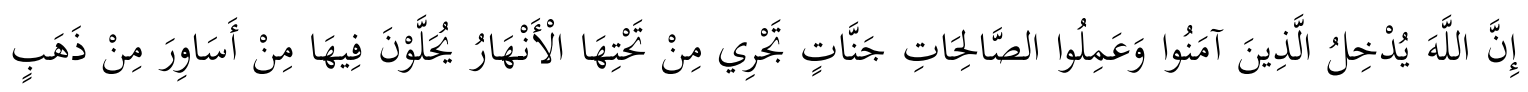

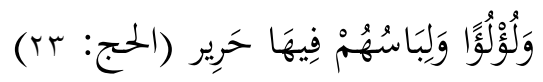

"Indeed, Allah will include those who believe and do righteousness into the heavens that flow underneath the rivers. There they were given jewelery with gold and pearl bracelets, and their clothes were made of silk"

\section{Prophet Traditions on Silk}

\section{Texts of Hadith on Silk}

History of the traditions that discuss about silk is very diverse. Starting from the hadith fi'li, a narration about Rasulullas Saw using silk, to the taqriri hadith. There are narrations that explain the Messenger of Allah had used silk, there are also traditions that describe the Prophet forbid his people to use silk. In a narration it is said that the Prophet had worn a robe made of silk, which was a gift from someone, as the account in the narration of Anas bin Malik's history:

8 Edmund Burke Feldman, Art as Image and Idea (New Jersey: Prentice Hall, 1967), p. 138-218.

9 Pangeran Paita Yunus, Soedarsono, dan SP Gustami, "Unsur Estetika Islam Pada Seni Hias Istana Raja Bugis," Jurnal Al-Ulum 12, no. 1 (2012), p 41.

10 Suharso dan Ana Retnoningsih, "Kamus Besar Bahasa Indonesia” (Semarang: Widya Karya, 2005), p. 509.

11 Ahmad Mukhtar Umar, dalam Mu'jam al-Lughah al-'Arabiyyah al-Mu'ashirah (Kairo: Alam al-Kutub, 2008), p.470. 


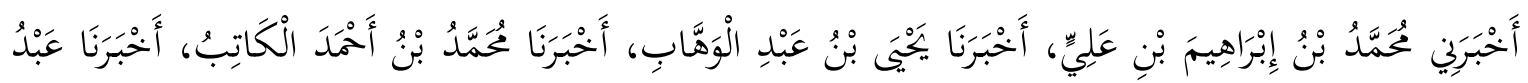

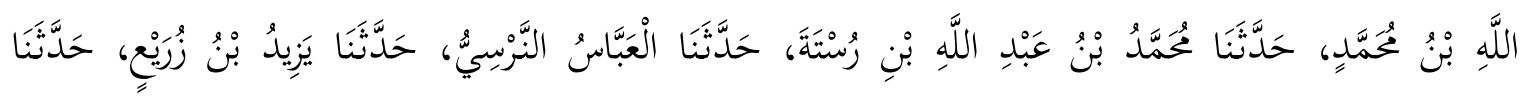

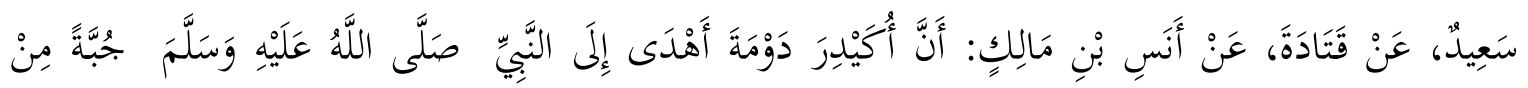

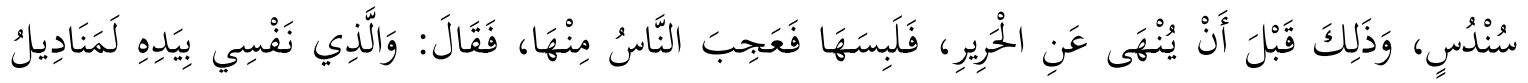

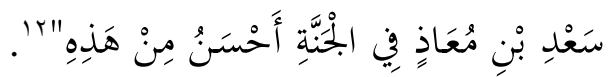

"Has preached to me Muhammad ibn Ibrahim ibn Ali, has told us Yahya bin Abdul Wahhab, has told us Muhammad bin Ahmad al-Katib, has told us Abdullah bin Muhammad, has told us Muhammad bin Abdullah bin Muhammad, has told to we Muhammad bin Abdullah bin Rustah, told us al-Abbas ad Darsiy, told us Yazid bin Zurai ', told us Sa'id, from Qatadah, from Anas bin Malik, actually Ukaidir Daumah gave a gift to the Prophet a sermon from silk, and that was before the prohibition on using silk, then he used it, and people were amazed or amazed, then he said "For the sake of the Essence that I am in His hands really handkerchiefs Sa'ad bin Mu'adz in heaven better than this".

In the Hadith there are two words that indicate the meaning of silk, namely Sundus and harir. The term sundus means silky silk as mentioned in the following verse of the Qur'an:

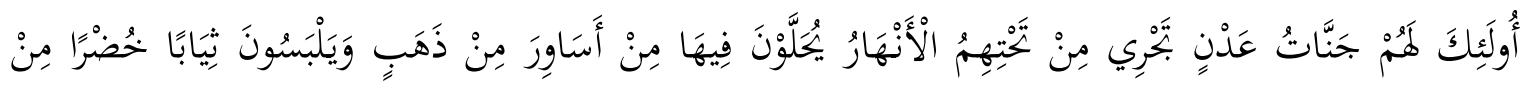

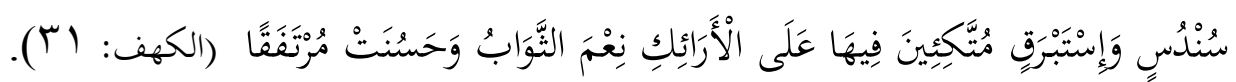

"It is they who obtain the paradise "Adn, which flows underneath the rivers; (in that heaven) they were given a gold bracelet and they wore green garments of fine silk and thick silk, while they sat leaning on beautiful couches. (That is) the best reward, and a beautiful resting place ".

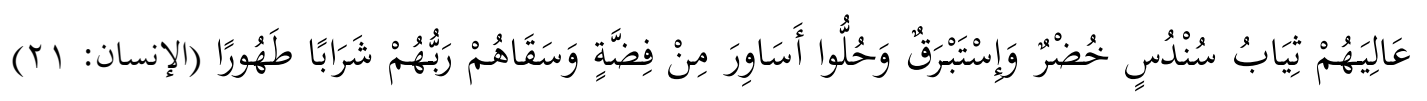

"They dressed in fine, green silk and thick silk and wore bracelets made of silver, and God gave them a clean drink (holy) ".

In another hadith it was also reported that the Prophet had worn a coat made from silk decorated with buttons of gold. As the hadith.

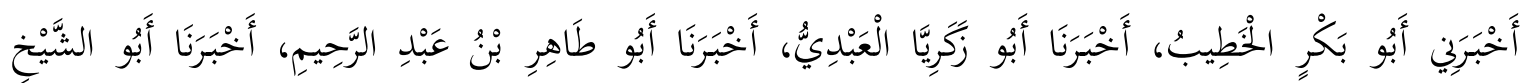

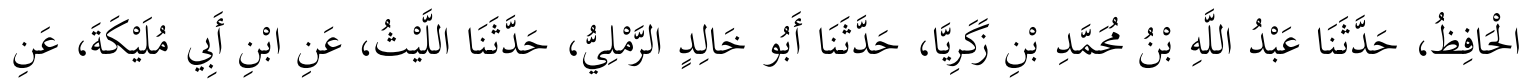

12 Bukhari, Al-Jami' al-Shahih, p 578. 


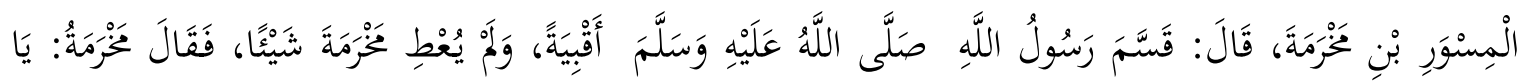

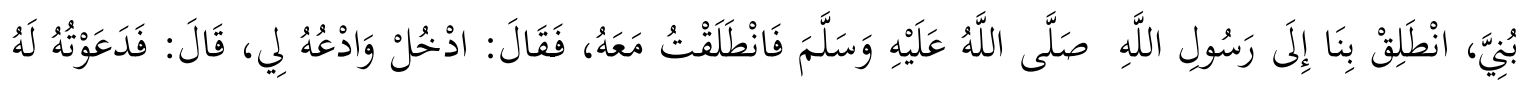

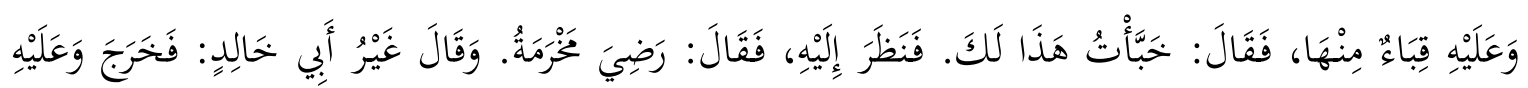

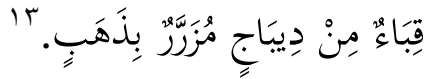

"Has preached to me Abu Bakar al-Khatib, has preached to us Abu Zakariya al'Abdy, has preached to us Abu Thohir bin 'Abdir Rahim, has preached to us Abu Shaykh al-Hafidz, has told us' Abdullah bin Muhammad bin Zakariya, told us Abu Khalid ar-Ramli, had told us al-Laitsi, from Ibn Abi Mulaikah, from Miswar bin Makhramah said: "The Messenger of Allah distributed the outer garments (coats) and did not give to Makhramah anything, then Makhramah said: "O my son, let's go to the Messenger of Allah", then he went with him. He said "come in and call him for me", then I called him and he came out wearing a coat from him, then he said: "You have hidden, and this is for you. He looked at him and said that Makhramah was satisfied. Besides Abu Khalid said then he came out wearing a coat of clothes from silk and gold buttons".

In other narrations the Prophet shows that he did not like silk clothing, as contained in the hadith.

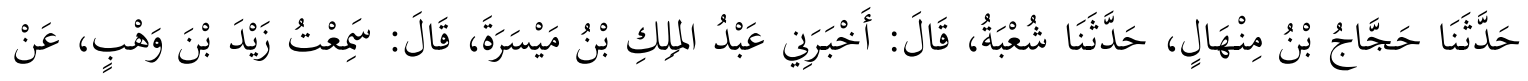

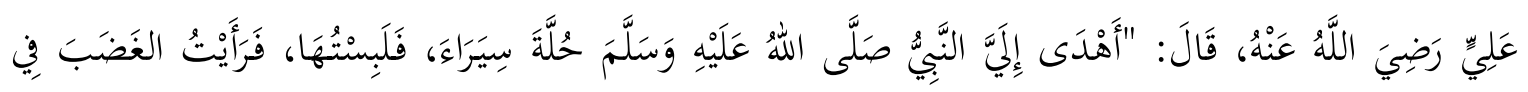

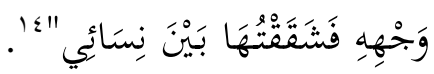

"Has told us Hujjah ibn Minhal, has told us Syu'bah, he said: has preached to me 'Abdul Malik bin Maisarah, he said: I heard Zaid bin Wahbin, from Ali RA, he said: "The Prophet gave me a gift of silk, so I wore it, then I saw the angry expression on the face of the prophet, so I gave silk to my wife".

The Prophet's message on the practice of the use of gold and silk in several texts was addressed in general terms, not specific to certain sexes. As the following hadith:

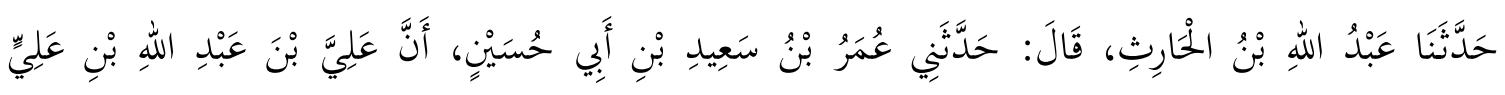

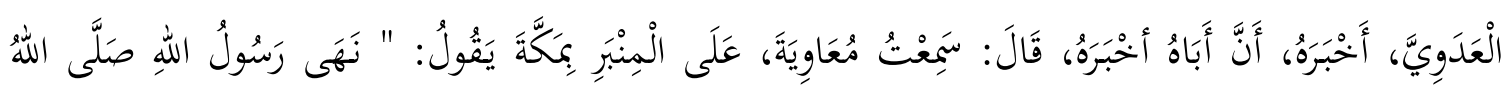

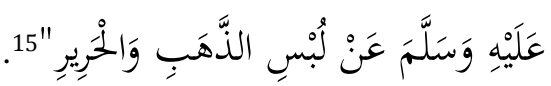

"Having told us Abdullah bin Harith, he said: told me Umar bin Sa'id bin Abi Husain, indeed Ali bin Abdillah bin Ali al-'Adawiy, had told him that his father had

\footnotetext{
13 Bukhari, p 589.

14 Bukhari, p 589.

15 Bukhari, p 430.
} 
told him: I heard when Mu'awiyah was in on the pulpit in Mecca said: "The Messenger of Allah has banned using gold and silk."

\section{Ethical Value of Hadith on Silk}

The general ban contains the Prophet's message to all humanity about the ethical value that the grandeur and pride of lifestyle can be experienced by all parties, both men and women. There are also other traditions:

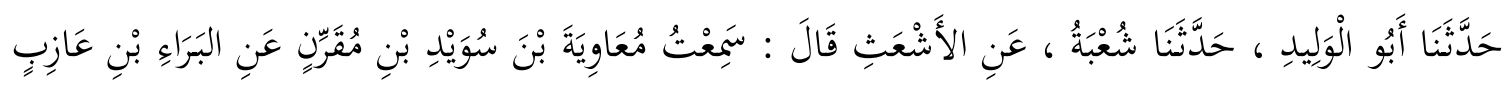

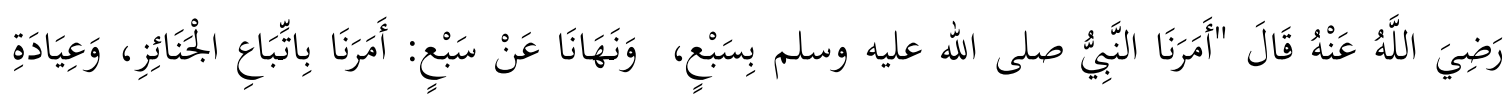

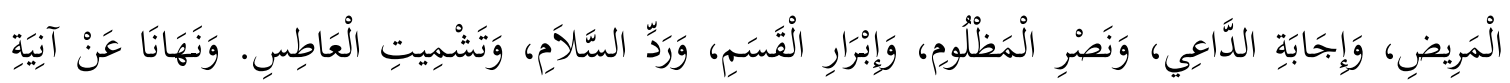

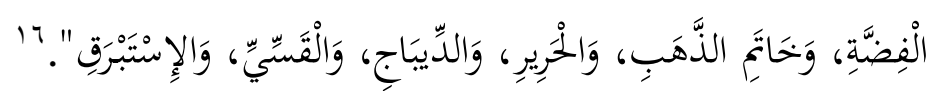

"Has told us Abu al Walid, told us the Syu'bah from al Ash'ats said: I have heard from Mu'awiyah bin Suwaid bin Muqarrin, from al Barra 'R.A. said: The Prophet has ordered us seven things and prohibited us from seven things. Ordered us to accompany the body, see the sick, answer calls, help the wrongdoers, fulfill oaths, answer greetings, and give thirsty people a drink. And forbid us from using silver containers or containers, wearing gold rings, silk, dibaj, qasiyyi, and istabraq".

As technology develops, the terms and types of silk continue to change. For this reason, in analyzing changes in contemporary culture with some rules on the use of silk in the hadith, it is necessary to refer to the rules explained by Abdurrahman as-Sa'di. According to him to face a change and cultural differences Muslims need to see from three aspects. The three aspects are time, 'urf (culture or custom), and rawatib. ${ }^{17}$

With changes in time, an object or value of goods will continue to change and develop. So in determining attitude, it needs to be conditional and contextual. Not always something that is prohibited or unnatural in the past continues to be valid until now. Then stand on these three aspects before determining a decision in response to change, the results will be more flexible and wiser. Islam is more adaptive, not seen as a rigid and hard religion.

Silk besides being used as clothes can also be used for therapy or medicine. Friends of Abdurrahman bin 'Auf and Zubair had experienced skin diseases and then wore silk clothes as therapy or medicine. As in the history of the following traditions:

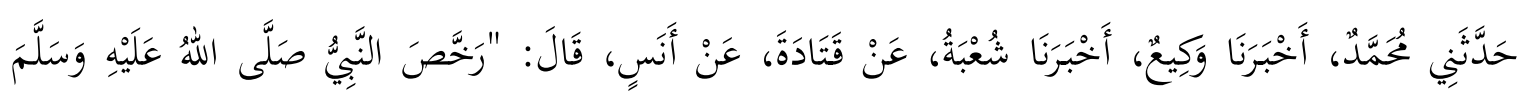

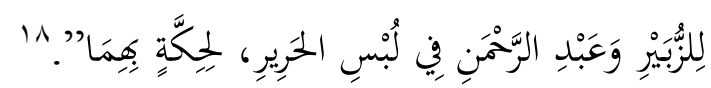

\footnotetext{
${ }^{16}$ Bukhari, p 383.

17 Abdurrahman As-Sa'di, Qawa'idul al-Hisan (Beirut: Dar al-Fikr, t.t.), p 345.

18 Bukhari, Al-Jami' al-Shahih, p 587.
} 
"For telling me Muhammad, for preaching us Waki, for telling us Shu'bah, from qatadah from anas, he said: "The Messenger of Allah has given mercy to Zubair and Abdurrahman to use silk because of scurvy or itchiness that afflicts both of them".

In the text of the hadith begins with the word rakhkhasa which means to ease, facilitate, or the Prophet gave rukhshah. Rukhshah is relief or release from obligation. The use of the word rakhkhasa is because in the previous history silk was prohibited for men. While the two companions who complained to the Prophet were men. So that the relief referred to in the hadith shows that it is permissible to use silk for men on the grounds that it is a medicine for suffering from an illness.

\section{Aesthetic Values of Hadith on Silk}

The aesthetic value contained in some of the traditions around silk can be seen from the aspect of form, structure, and meaning of various silk terms. In general, identical silk is expressed by the recitation of harir. However, there are several other terms used in the hadith to denote silk, that is, there are about six terms including harir.

First, the term harir which means a type of clothing that is smooth and contains silk. ${ }^{19}$ In the aspect of meaning, the word harir comes from the root word harra which means warm and noble. ${ }^{20}$ From the root of the word comes the adjective harrun, which means warm or hot. This is in accordance with the nature of silk that can warm the body of the wearer, and become a symbol of noble and valuable clothing.

Second, the term dibâj which means clothes woven with ties or thread from silk. The root of the word dibaj is dabaja, which means to decorate, paint, and embellish. The term was originally a Persian language which was later absorbed into Arabic. ${ }^{21}$ From the basic meaning it has a relation to the characteristics of dibâj which can beautify and decorate the body and other decorations.

Third, the term qasiy is a kind of clothing made in Egypt with silk. Qasiy comes from the word qasa which means hard, ugly or fake. ${ }^{22}$ The word also has the meaning of fake dirhams. From some of the basic meanings shows that qasiy is clothing with silk material of low quality or a kind of imitation.

Fourth, the term sundus, according to the mufassir, means silky or soft silk. Linguists agree that the word is an adopted language that has become Arabic. ${ }^{23}$ So that in some Arabic dictionary literature, no root word is found from Sundus.

Fifth, the term istabraq silk is thick and good. The term is basically an absorption word from Persia. According to some linguists, the term istabraq comes from the root word

\footnotetext{
19 Umar, p 470.

20 Ahmad bin Faris Al-Qazwini, "Mu'jam Maqayis Al-Lughah” (Beirut: Dar al-Fikr, 1979), p 468.

21 Ibnu Mandhur, "Lisan al-‘Arab” (al-Dar al-Misriyyah, t.t.), p 1316.

22 Mandhur, p 3633.

23 Mandhur, p 2177.
} 
baraqa and the letters hamzah, sin, tâ` are additional letters. In language baraqa means to shine or sparkle. ${ }^{24}$

Sixth, the term siyara is a clothing that is mixed or patterned lines of silk alloy, this type of clothing originates from Yemen. Besides the term siyara also sometimes means gold or jewelry. ${ }^{25}$ The term siyara comes from the root of a word consisting of the letters sin, yâ, râ which means to walk, exit or pass. ${ }^{26}$ The meaning is related to the characteristics of siyara known as patterned lines, meaning that line patterns can be compared to or passing through plain cloth in a long and time-consuming process.

From some of these terms it can be understood that the different terms for describing silk clothing are related to the level of quality. From clothes made from silky smooth, thick, and only variations. This shows the aesthetic value of the various types of silk clothing in the Prophet's traditions.

\section{E. Conclusion}

Ethical values in the traditions around silk can be grouped into four. First, ethics so that Muslims have a firm identity, not relying on other people. Second, ethics so that Muslims avoid arrogance and overdoing in decorating. Third, ethics cares about social affairs and lives simply. These three ethics generally show the Prophet's recommendation that Muslims not be selfish or only think of prestige, honor and individual affairs.

The aesthetic value of silk in the hadith can be seen from a variety of terms used to indicate the meaning of silk. There are six pronunciations in the text of the hadith that refer to clothing made from silk, namely the recitation of harir, dibâj, qasiy, sundus, istabraq, siyara`. The six terms indicate that at the time of the Prophet there were silk variants with various forms, motifs, and levels of quality. This shows the aesthetic value of the variety of clothing made from silk material during the Prophet's time is the uniqueness and variation of the pronunciation used by the Prophet to describe the shape and structure of various types of silk.

\footnotetext{
24 Atabik Ali dan A. Zuhdi Muhdlor, "Kamus Kontemporer Arab Indonesia” (Yogyakarta: Multi Karya Grafika, 2003), p 317.

25 Mandhur, "Lisan al-‘Arab", p 2170.

26 Ali dan Muhdlor, "Kamus Kontemporer Arab Indonesia", p 1104,
} 


\section{Bibliography}

Ali, Atabik, dan A. Zuhdi Muhdlor. “Kamus Kontemporer Arab Indonesia.” Yogyakarta: Multi Karya Grafika, 2003.

Al-Qazwini, Ahmad bin Faris. “Mu’jam Maqayis Al-Lughah.” Beirut: Dar al-Fikr, 1979.

As-Sa'di, Abdurrahman. Qawa'idul al-Hisan. Beirut: Dar al-Fikr, t.t.

At-Tirmidzi, Muhammad. Sunan al-Tirmidzi. Riyadl: Maktabah al-Ma'arif, 1417.

Bukhari, Abu Abdullah Muhammad. Al-Jami' al-Shahih. Kairo: al-Mathba'ah as-Salafiyyah, 1400.

Feldman, Edmund Burke. Art as Image and Idea. New Jersey: Prentice Hall, 1967.

Ismail, Syuhudi. Metodologi Penelitian Hadis Nabi. Jakarta: Bulan Bintang, 1992.

Khon, Abdul Majid. Ulumul Hadis. Jakarta: Amzah, 2010.

Mandhur, Ibnu. “Lisan al- 'Arab.” al-Dar al-Misriyyah, t.t.

Muhadjir, Noeng. Metodologi Penelitian Kualitatif Pendekatan Positivistik, Rasionalistik, Phenomenologik, Dan Realisme Metaphisik Telaah Studi Teks dan Penelitian Agama. Yogyakarta: Bayu Indra Grafika, 1998.

Sardila, Vera. "Implementasi Pengembangan Nilai-Nilai Etika dan Estetika Dalam Pembentukan Pola Prilaku Anak Usia Dini.” Jurnal RISALAH 26, no. 2 (Juni 2015): 86-93.

Shihab, Quraish. Wawasan Al-Qur'an. Jakarta: Mizan, 2007.

Suharso, dan Ana Retnoningsih. “Kamus Besar Bahasa Indonesia.” Semarang: Widya Karya, 2005.

Syamsuddin, Muhammad. "Eksistensi Manusia menurut K.H. Ahmad Azhar Basyir." Sosio Religia Jurnal Ilmu Agama dan Ilmu Sosial 4, no. November (2004): 131-47.

Umar, Ahmad Mukhtar. Mu'jam al-Lughah al-'Arabiyyah al-Mu'ashirah. Kairo: Alam alKutub, 2008.

Yunus, Pangeran Paita, Soedarsono, dan SP Gustami. "Unsur Estetika Islam Pada Seni Hias Istana Raja Bugis.” Jurnal Al-Ulum 12, no. 1 (Juni 2012): 35-52. 